Louisiana State University LSU Digital Commons

Faculty Publications

Department of Geography \& Anthropology

2012

\title{
The role of blacks in establishing cattle ranching in Louisiana in the eighteenth century
}

Andrew Sluyter

Louisiana State University, asluyter@lsu.edu

Follow this and additional works at: http://digitalcommons.lsu.edu/geoanth_pubs

\section{Recommended Citation}

Sluyter, Andrew, "The role of blacks in establishing cattle ranching in Louisiana in the eighteenth century" (2012). Faculty Publications. 21.

http://digitalcommons.lsu.edu/geoanth_pubs/21

This Article is brought to you for free and open access by the Department of Geography \& Anthropology at LSU Digital Commons. It has been accepted for inclusion in Faculty Publications by an authorized administrator of LSU Digital Commons. For more information, please contact gcoste1@lsu.edu. 


\title{
The Role of Blacks in Establishing Cattle Ranching in Louisiana in the Eighteenth Century
}

\begin{abstract}
ANDREW SLUYTER
A longstanding assumption posits that white ranchers from the French Caribbean colony of Saint-Domingue, now Haiti, provided the knowledge to establish the first cattle ranches in Louisiana in the mid-eighteenth century, that blacks merely provided the labor, and that the herding ecology involved was the same as that of the Acadian ranchers who followed. Reconstruction of the locations of the first major ranches and the backgrounds of their owners and slaves, however, reveals that none of them came to Louisiana from Saint-Domingue and that the ranches occupied the western margin of the Atchafalaya basin, an environment quite different than the prairies of southwestern Louisiana later inhabited by Acadian ranchers. While the sources cannot yield a complete account of the process through which cattle ranching became established, they do suggest that none of the white ranchers brought relevant experience from the Caribbean or France, that some of the blacks might have brought such experience from Africa, and that people of African, European, native, and mixed origins all contributed knowledge and creativity, as well as labor, in founding a distinctive herding ecology that differed substantially from that of the subsequent Acadian ranches.
\end{abstract}

A 1766 LOUISIANA CENSUS RAISES THE possibility that blacks might have played a major creative role in establishing cattle ranching in that part of North America despite the longstanding assumption that white ranchers from the French Caribbean colony of Saint-Domingue, now

ANDREW SLUYTER has studied and worked in Vancouver, Austin, Buenos Aires, Barcelona, and Baton Rouge, where he is currently an associate professor of geography at Louisiana State University. His research has amplified understanding of the colonization of the Americas, particularly regarding long-term changes in agricultural landscapes. His publications include the monograph Colonialism and Landscape (2002), which won the 2004 James M. Blaut Award of the Association of American Geographers.

(C) the Agricultural History Society, 2012

DOI: $10.3098 /$ ah.2012.86.2.41 
Haiti, provided the knowledge, while blacks merely provided the labor. The summary table of the census records each militia post's number of households, men and women, male and female adolescents and children, slaves, area of land granted, equines, cattle, other livestock, and muskets- the last hardly surprising given that Louisiana had just become the North American frontier between the Spanish and British empires. One of the rows in the table claims that the first large group of Acadians to arrive in Louisiana had acquired a herd of one thousand forty head of cattle and three hundred twelve other livestock within a year of settling along Bayou Teche near the Attakapas Post in April 1765, despite the government having supplied the nearly fifty households with seed to grow rice and maize, but not with livestock (Figure 1). The row most directly relevant to the role of blacks in the establishment of cattle ranching reads "Five old cattle ranches in the Attakapas District": no households or militia, fifty slaves, two leagues of land granted, fifteen thousand cattle, three hundred horses, one hundred other livestock, and fifty muskets. Since the table totals all of Louisiana's cattle at 28,491 and reveals that no other district had more than 2,500 head, it implies that fifty enslaved blacks armed with muskets were riding around without any direct supervision by whites on five neighboring ranches that contained more than half of the colony's cattle. Somehow, between the

Figure 1. Lower Louisiana in the Eighteenth Century.

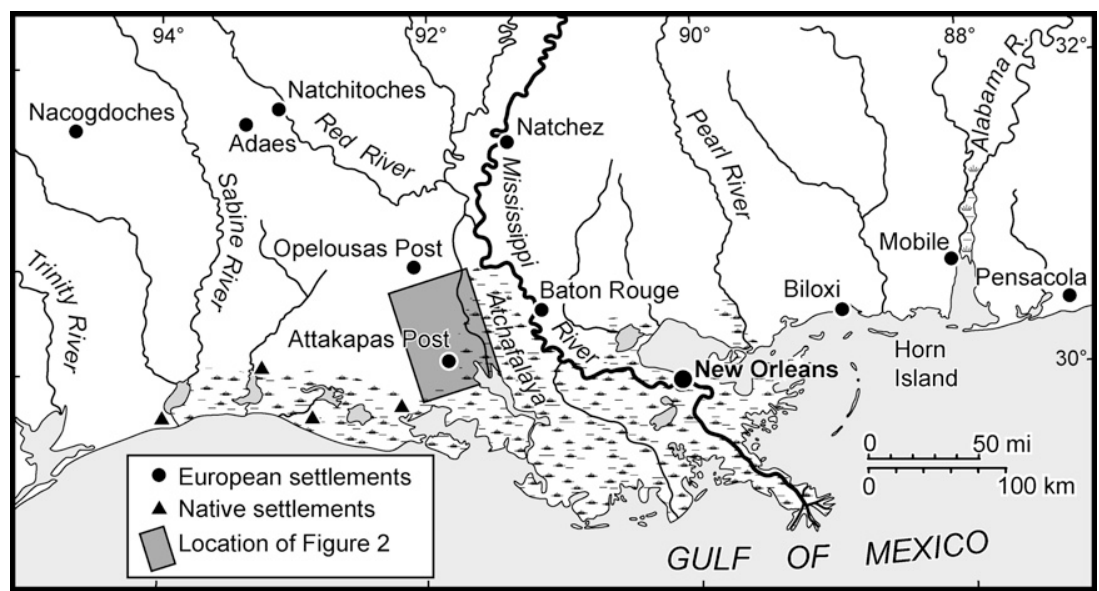

Map by author based on sources cited in the text. 
initial incursions of traders into the Attakapas in the 1730s and the influx of Acadians three decades later, five ranches in that district apparently came to dominate cattle herding in all of Louisiana-and blacks had come to dominate those ranches. ${ }^{1}$

Previous scholarship largely ignores pre-Acadian ranching and therefore does not offer a description of those ranches or an understanding of how they became established and how blacks came, apparently, to operate them. Lacking the research, scholars have simply assumed that the earliest ranching in Louisiana derived directly from the French Caribbean, principally Saint-Domingue, and therefore ultimately from Spanish antecedents on Hispaniola. The much larger literature on Acadian ranching certainly acknowledges the existence of pre-Acadian ranching but assumes the two employed identical herding ecologies. Moreover, that literature emphasizes the roles of whites because Acadians in the Attakapas did not acquire many slaves until the nineteenth century. ${ }^{2}$

The voluminous documentation generated as the federal government vetted claims to private property after the Louisiana Purchase of 1803 reveals that only five land grants in Attakapas predate 1771, the year Acadians received their first grants. The French caretaker government did not grant Acadians land upon arrival in 1765, and their participation in the 1768 rebellion that ousted the first Spanish governor, Antonio de Ulloa, did not encourage the new regime to grant them land for several years thereafter. Only under the third Spanish governor, Luis de Unzaga y Amezaga, did Acadians receive grants, beginning with two dozen in 1771 and following with twice that many the next year. ${ }^{3}$

Figure 2 locates the five pre-1771 grants and indicates their years of initial occupation, the year of the French grant, and that of any subsequent Spanish grant. André Massé established the first ranch in the mid-1740s and in October 1763 requested a grant based on that long occupancy. But its award awaited arrival of the Acadians. Then the French caretaker government, headed by Charles Philippe Aubry, brokered a deal by which Massé and Jean Antoine Bernard Dauterive would provide the new settlers with a small herd of cattle and land at the Attakapas Post. They would raise those cattle and annually turn some of the growing herd over to Dauterive. In exchange, he and Massé would jointly receive a grant for a tract as vast in extent as its boundaries were vague: an area known as the Vermillion Prairie. The deal with the Acadians fell through 
Figure 2. Pre-Acadian Ranches of the Middle Teche Valley.

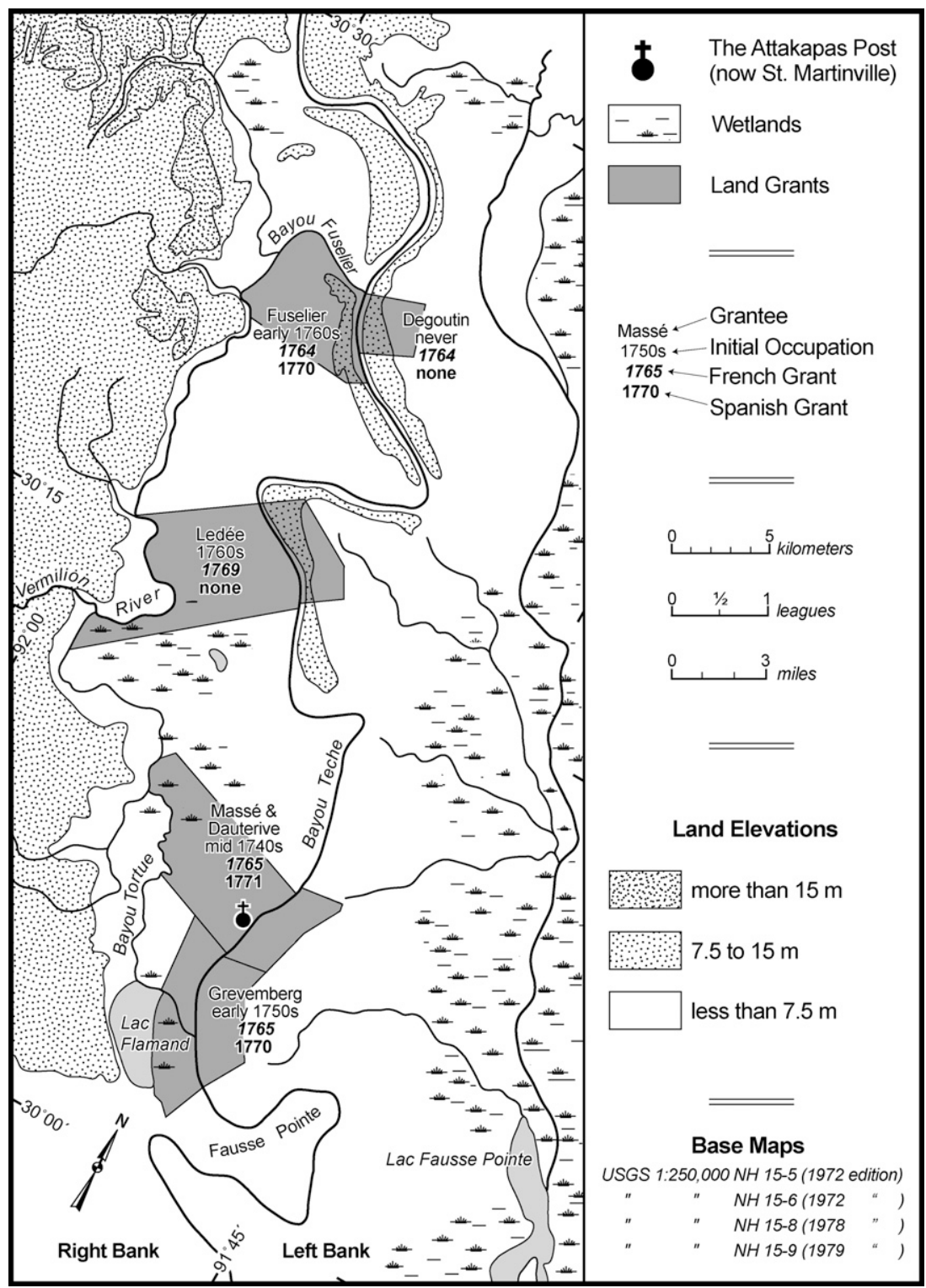

Map by author based on sources cited in the text. 
when they chose to settle several kilometers downstream, at Fausse Pointe, and purchase cattle from Jean Baptiste Grevemberg. Massé remained on his ranch at the Attakapas Post, but in 1771 Dauterive claimed he had purchased his partner's share and successfully solicited a grant for the tract from Unzaga. The federal government accepted the claims for private lands founded on that grant and surveyed them as the sections on the original township plats that Figure 2 maps. ${ }^{4}$

Four other ranchers followed Massé's initiative in requesting land grants in the Attakapas. In the early 1750s Grevemberg purchased land from trader Charles Toutin, who had purchased the land from another trader, Joseph Blancpain, who had purchased the land from the Ishaks. In 1765 Grevemberg successfully petitioned Aubry for a grant that formalized his occupation of that land while, at the same time, arguing that the Acadians should not receive grants even though he had sold them some cattle. Like Massé, Grevemberg requested an enormous tract with vague boundaries, its focal point being Fausse Pointe. After the second Spanish governor, Alejandro O'Reilly, issued an ordinance in 1770 that no land grant should exceed one square league, Grevemberg petitioned to ratify a reduced version of the earlier grant. This second grant did not extend far enough downstream to include Fausse Pointe because many of the Acadians had already settled there. The third pioneer rancher, Gabriel Fuselier de la Claire, purchased two leagues of land from the Ishaks in November 1760, ratified by a grant in 1764 from Aubry's predecessor, Jean Jacques Blaise d'Abbadie. The 1770 ordinance spurred Fuselier, like Grevemberg, to petition for a Spanish grant for the smaller area mapped on Figure 2. Jean François Ledée, the fourth pioneer rancher, purchased a tract of land on March 8, 1762 from André Jung, who himself had purchased the land from the Ishaks. In 1769, presumably prompted by the influx of Acadians, Ledée sought to improve his title by petitioning for a grant from Aubry. Aubry granted the tract mapped on Figure 2, and Congress accepted all claims founded on it. The last relevant grant pertains to Joseph Deville Degoutin. On June 13, 1764 he received a grant from d'Abbadie for a tract of 2,500 arpents (a measure of both distance and area equal to 58.5 meters and 0.3424 hectares) on the left bank of Bayou Teche. ${ }^{5}$

To be clear, Figure 2 maps the locations of the cores of the five preAcadian grants rather than more extensive, vaguely bounded predecessors. 
As Grevemberg claimed in his 1765 petition, the original sales or grants to him and the others had been much larger:

no determinate quantity being expressed in the sale by which the land was conveyed to him, the memorialist has not considered himself confined to any quantity, particularly as the quantities claimed by Massé and Dauterive, Ledée, Fuselier, and Courtableau, which reach to the sea and for much larger quantities than that claimed by the memorialist, have never been disputed by any person.

During the 1760s, however, such enormous land holdings became progressively untenable, especially after the arrival of the Acadians encouraged earlier ranchers to seek more secure title for their core tracts. The Grevemberg case illustrates the process: by 1760 initial acquisition through purchase from the Ishaks of immense but vaguely bounded tracts; during the 1760s successful opposition to grants for newly arrived Acadians and confirmation of titles through grants from the outgoing French government; in 1770, as the new Spanish government limited grants to a maximum of one square league, retreat to even smaller core tracts in exchange for better-defined boundaries and secure title. ${ }^{6}$

Along with land, cattle represented the other non-human element involved in the herding ecology of the five ranches. The 1766 census provides their first enumeration, but livestock had arrived on the banks of Bayou Teche long before. Feral horses and cattle derived from Spanish efforts to colonize Texas constituted part of the French trade with natives during the early eighteenth century. As the French and Spanish increasingly settled the Louisiana-Texas frontier, a contraband trade developed in which cattle made up part of the eastward flow. In contrast, only a small proportion, if any, of the cattle grazing along Bayou Teche by 1766 had come westward, introduced through New Orleans and Mobile from Saint-Domingue, Cuba, Florida, and Veracruz. All the many cattle that came from Texas and the few through New Orleans ultimately derived from the Spanish livestock of Hispaniola and would have been lean, rangy longhorns. ${ }^{7}$

While the 1766 census provides the first enumeration of cattle, its use is limited. The summary table claims that sixteen thousand forty head of cattle grazed the Attakapas: fifteen thousand on the five old ranches and 
another one thousand forty belonging to fifty Acadian households. Yet only forty-seven Acadian households appear in the census's detailed tables and only five of them had any cattle at all: three with one animal each, another with two, and the last with seven, totaling a mere dozen head, far short of one thousand forty. Apparently, the Acadians had not really amassed an average of more than twenty head per family within little more than a year, as the summary table claims. In fact, other documents reveal that the Acadians had a difficult time acquiring their initial cattle. In April 1765 they signed the contract with Dauterive to settle on his and Massé's ranch and raise some of their cattle in return for half the increase after six years. Each of eight families would receive a bull, five cows, and five calves. But the Acadians never consummated that contract and instead settled at Fausse Pointe and purchased about a dozen head from Grevemberg. ${ }^{8}$

The census is also inconsistent in regards to the larger non-Acadian herd. The majority of the cattle were on the Massé and Dauterive ranch: Dauterive owned ten thousand head and Massé twenty. Only eight of the remaining four thousand eighty head claimed in the summary table appear under someone else's name, that of Antoine Bonin. Ledée, Grevemberg, and Fuselier do not appear in the census in any jurisdiction, despite owning large tracts of land. Degoutin does appear in the enumeration for New Orleans but with no cattle to his name. ${ }^{9}$

Other sources imply that the 1766 census missed some cattle. A 1756 letter by Jacinto de Barrios, then the Spanish commandant at the Adaes Post in Texas, suggests that Massé may have had more than the twenty head the census reports, stating that just ten years prior he had owned seven hundred. In Grevemberg's 1765 petition, he claimed to have more than three thousand head. Conjecture suggests that Ledée, Degoutin, and Fuselier might have accounted for some of the remainder of the fifteen thousand non-Acadian cattle noted in the summary table. The census of 1771 comes too late, six years after the arrival of the Acadians, to do more than echo the situation in the mid-1760s but lists the following: Fuselier with four hundred fifty cattle, Dauterive with no cattle mentioned but one-and-a-half leagues of land; Massé with three hundred cattle, Grevemberg with three hundred head, and Ledée with four hundred fifty head of cattle. Two years later, in 1773, Dauterive claimed he had six thousand livestock in the Attakapas. ${ }^{10}$ 
The overall assessment must be that the 1766 census accurately captured the size of the non-Acadian herd, with Dauterive owning the vast majority of cattle, a herd in the thousands, possibly approaching as many as ten thousand. Grevemberg followed with a smaller herd, but still in the thousands. Massé, Fuselier, and Ledée each owned hundreds of cattle but fewer than one thousand. Degoutin had no cattle.

Brand registries complement censuses as a source for locating cattle. Of the some twenty-five thousand brands in the three earliest brand books for the Attakapas, several predate the arrival of the Acadians in 1765 , with the first entries dating to the late 1730s. Several other entries predate the flood of Acadian brand registrations that began in 1766, as they acquired cattle before acquiring land titles in $1771 .^{11}$

The earliest brands date to 1739 and have the names of two of Grevemberg's five sons: Louis and Barthélémy (Figure 3). Louis, however, would have been about four that year and Barthélémy was not born until the mid-1750s. This implies that the brand registry did not really begin until at least the mid-1750s, shortly after Grevemberg purchased and occupied his tract in the Attakapas, and that he backdated the brands for his eldest and youngest sons. Neither Grevemberg himself, his three other sons, Fuselier, Degoutin, Ledée, Massé, nor Dauterive registered brands before the Acadian registrations began in 1766, but three other ranchers did, all of them somehow associated with Massé. Jacques Joseph Sorrel, a protégé of Massé, supposedly registered a brand in 1758 . The 1766 census does not list Sorrel, but the 1771 census lists him with one hundred eighty head of cattle and lacking title to land. Bonin, another Massé associate registered a brand in 1764, the censuses crediting him with eight cattle in 1766 and twentyfour in 1771, but lacking title to land. Bonin was married to Marie Marguerite Tellier and related to the George Tellier who registered a brand in $1761 .{ }^{12}$

In sum, the pre-Acadian ranchers ranged from those like Dauterive with herds in the thousands to those with herds of a dozen or fewer head like Bonin. The large ranchers had title to thousands of hectares and mainly did not trouble to register their brands until well after the Acadians arrived. The small ranchers lacked title to land and therefore had more incentive to register the brands that marked the property that they did own, namely their cattle. Massé played an intermediary role between the 
Figure 3. Brands Relevant to Pre-Acadian Ranching in the Middle Teche Valley.

\begin{tabular}{|c|c|c|}
\hline BRAND & YEAR & NAME \\
\hline & 1739 & Louis Grevemberg \\
\hline & 1739 & Barthélémy Grevemberg \\
\hline & 1758 & Jacques Joseph Sorrel \\
\hline & 1761 & George Tellier \\
\hline & 1764 & Antoine Bonin \\
\hline & 1775 & François Grevemberg \\
\hline$F$ & 1776 & François Grevemberg \\
\hline & 1779 & Barthélémy Grevemberg \\
\hline & 1784 & Gabriel Fuselier de la Claire \\
\hline$F$ & 1787 & Anne Judith Chenal (Dame Grevemberg) \\
\hline & 1799 & Jean François Ledée \\
\hline & no date & Jean François Ledée \\
\hline$G F$ & 1802 & Gabriel Fuselier \\
\hline
\end{tabular}

Image by author based on sources cited in the text.

large and small ranchers, in terms of the size of his herd and also because of his partnership with Dauterive on the one hand and his social associations with Sorrel, Bonin, and Tellier on the other. Degoutin seems to have been more a land speculator than a rancher, with no indication he ever owned any cattle in the Attakapas. ${ }^{13}$ 
Thus, the record clearly shows considerable land and cattle ownership in this area of Louisiana before the arrival of the Acadians. Scholars have assumed that this pre-Acadian herding ecology closely resembled that of the Acadians. But it was vastly different. The earlier settlers, located on the prairies of southwestern Louisiana, grazed large feral herds on open range with no interest in cropping. The Acadians, on the other hand, settled along Bayou Teche, combined small docile herds with crops of rice and maize. Such radically different herding practices resulted in conflicts, such as Acadian claims for crop damages and nonAcadian accusations of cattle rustling. In the closing decades of the eighteenth century, settlers along Bayou Teche shifted away from ranching toward plantation cropping, while the ranchers moved westward beyond the bluff that bounds Bayou Teche on the west, onto the prairies that stretch into eastern Texas. This new ranching environment did not provide good pasture during the winter, as the grass died back and became unpalatable, which forced ranchers to undertake long cattle drives to seasonal pasture in coastal marshes that, in turn, became untenable in summer due to hurricanes and insects. ${ }^{14}$

The location of the pre-Acadian ranches between the Teche Ridge and the bluff reveals how their herding ecology contrasted with later ranches established on the higher prairie lands west of the bluff (Figure 4). Bayou Teche created both the bluff and the Teche Ridge between thirty-five hundred and twenty-five hundred years ago, while carrying the combined flows of the Mississippi and Atchafalaya rivers. The flow cut the bluff that marks the western edge of the Atchafalaya Basin and created broad levées, forming the Teche Ridge as a cordon of high land within the basin. To the west, Bayou Tortue and the Vermillion River drained the backswamps between the Teche Ridge and the bluff. To the east, Bayou Teche's backswamps merged into those of the Atchafalaya. Along the Teche Ridge, bottomland hardwoods grew, with willow and cottonwood at the lowest elevations but grading into more open oak and hickory woodlands on the highest ground. In the backswamps, cypress and tupelo dominated the woody vegetation. Between the ridge and the backswamps, tall grasses and sedges thrived with the seasonal rise and fall of the floodwaters. That flood regime largely mimicked the Mississippi and Atchafalaya, with snowmelt upcountry creating the highest and most regular flooding every spring, but local heavy rains resulting in more minor flooding in any season. ${ }^{15}$ 
Figure 4. Idealized Transect across the Middle Teche Valley.

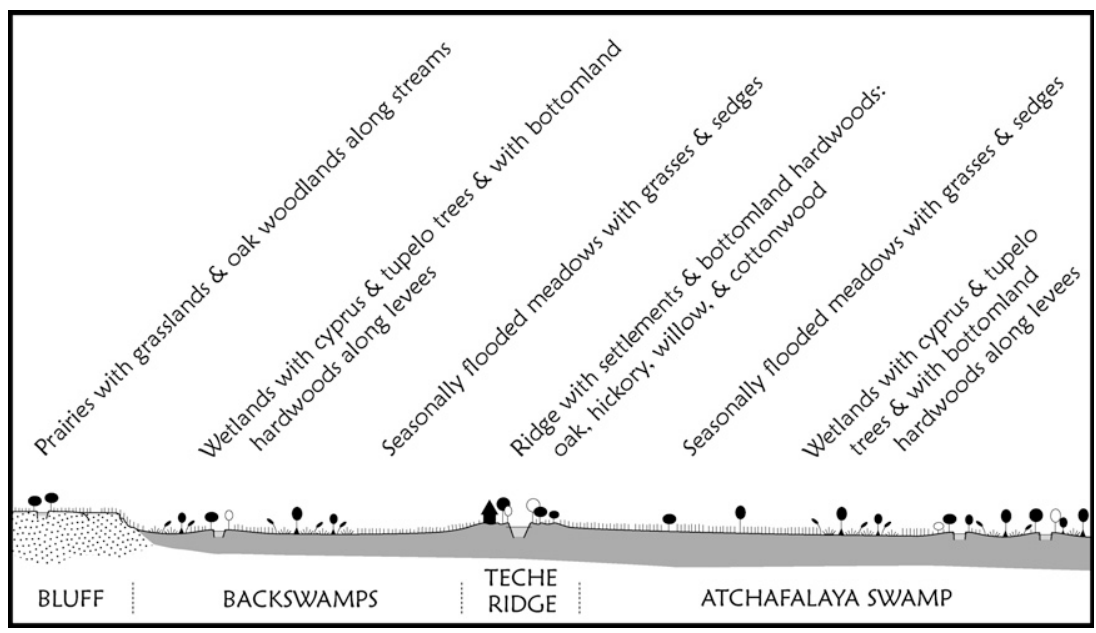

Image by author based on sources cited in the text and Kniffen and Hilliard, Louisiana, 51.

The strip of annually flooded grassland between the Teche Ridge and the bluff provided better pasture than either the swamps of the Atchafalaya to the east or the prairies to the west. The short elevational gradient between the higher and drier frontlands of the Teche Ridge and the lower and wetter backlands created an equally short hydrological and vegetational gradient that provided plentiful access to forage and water throughout the year, with the cattle moving up and downslope with the rise and fall of the floodwaters. Charles César Robin provided a revealing description of that landscape in the early nineteenth century, well after plantations had begun to supplant ranches but before extensive levées and drainage projects had entirely altered the patterns of vegetation and hydrology of the eighteenth century. He described how cattle foraged in complementary environments appropriate to each season. As floodwaters rose in the spring, herds moved into the open woodlands atop the Teche Ridge. As water receded through the summer, the cattle moved steadily downslope into the strip of lush grassland. Then, with winter, as the grasses died back and blue northers chilled the cattle, they moved into the margins of the backswamps among the canebrakes where they sheltered from the cold winds and foraged on the cane leaves, which remained green all winter. ${ }^{16}$ 
Ranchers and slaves brought diverse knowledge and practices thattogether with the lands and cattle along Bayou Teche-created a preAcadian herding ecology. None of the original ranchers had experience with raising cattle. Born in 1722 in Lyon, France, Gabriel Fuselier de la Claire was the youngest of three sons of a wealthy family of textile merchants with an estate called Le Grand Claire in Vaise and land in nearby Montigny (Figure 5). By 1748 he had left France for New Orleans as the representative of a consortium of textile merchants. He purchased the land in the Attakapas from the Ishaks in 1760, married a Louisiana

Figure 5. Places of Origin of the Pre-Acadian Ranchers.

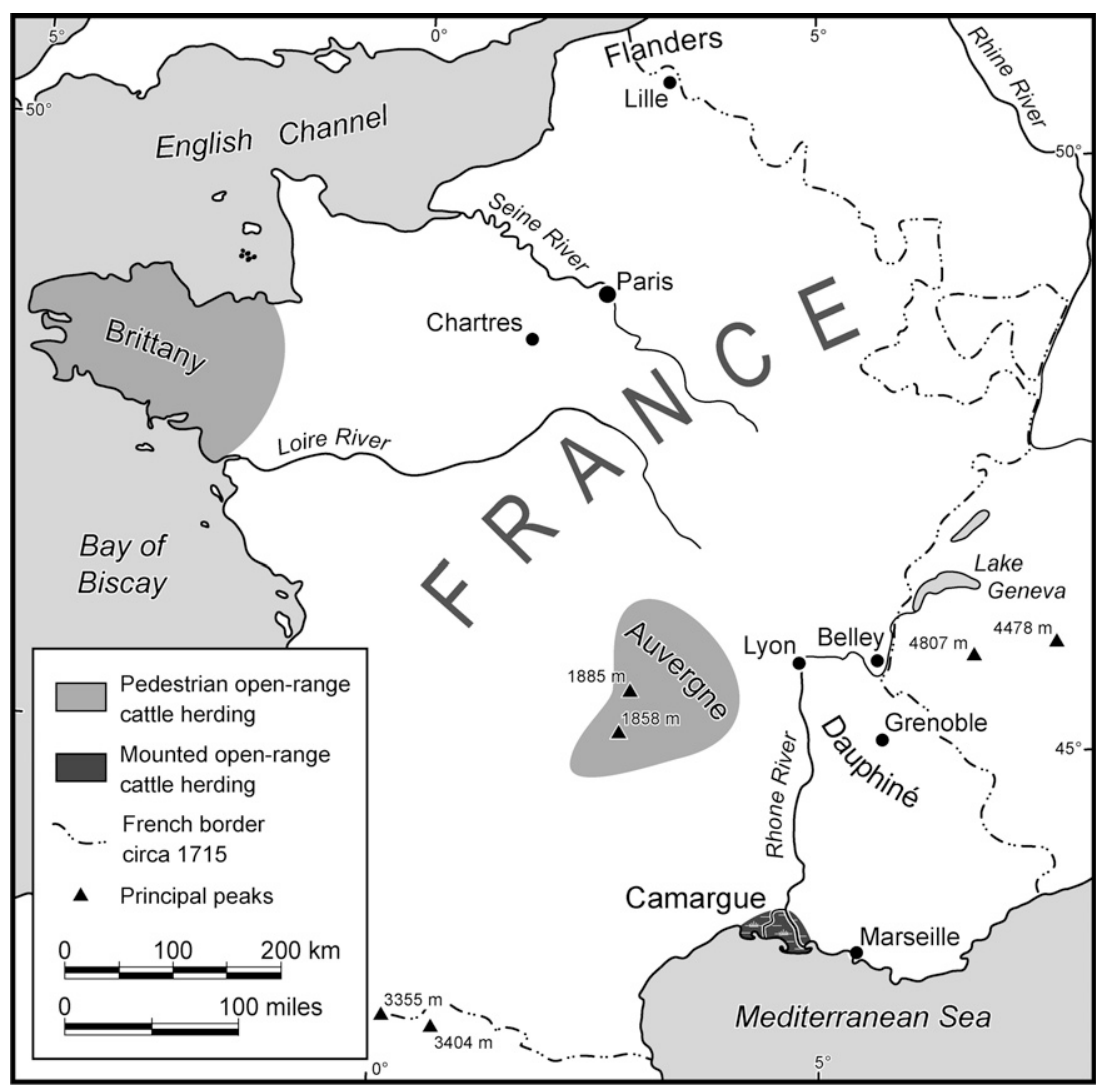

Map by author based on sources cited in the text and, for the eighteenth-century borders, Adolphus William Ward et al., eds., The Cambridge Modern History Atlas (London: Cambridge University Press, 1912), maps 46 and 79. 
creole (meaning she was born in the territory) named Jeanne Roman in 1764, and about that time became commandant at the Attakapas Post. After bearing a son and daughter, Jeanne died in 1770, the year Fuselier gained the additional position of commandant of the Opelousas Post. The next year he remarried another creole, Helene Elizabeth Soileau of Natchez. He retired as commandant in 1774 and died in Bordeaux on October 12, 1789 while on a business trip. ${ }^{17}$

André Massé was also born into a rich family of southwestern France, in Grenoble in 1700. He preferred nonetheless to live a modest life on the Louisiana frontier, where he could be "more a father than a master" to his many slaves. He may have come to New Orleans or Mobile originally in 1722 as a lieutenant in the military but by 1731 had acquired land along the Mississippi just upstream from New Orleans, near Dauterive and Blancpain. He established a ranch at the Attakapas Post about 1747, and from that base he traded with the Ishaks as far west as the Trinity River in Texas. In 1756 he and the first Catholic priest to serve the Attakapas Post, Pierre Didier, petitioned the viceroy of New Spain to found a settlement along the lower Trinity. They claimed that they wanted to more easily free Massé's slaves. Manumission required a petition to the government under the French Code Noir but not under Spanish law; thus a settlement under Spanish rule would be advantageous. The viceroy denied the petition, and Massé remained at the Attakapas Post, where he received a land grant in 1765 with his partner Dauterive. By 1771 Dauterive might have purchased Massé's interest in the ranch, but when Massé died intestate in 1775 a conflict ensued between his sister Claudine and his former partner over his property. ${ }^{18}$

Jean Antoine Bernard Dauterive was born in Belley, about halfway between Lyon and Grenoble, the son of a military officer named Bernard d'Auterive and Marie Jeanne St. Laurent. The family moved to New Orleans in 1719 for the father to assume the post of royal treasurer and by 1731 had acquired land just upstream from the city. Dauterive served as a captain in the military, married Elizabeth de Montault in 1764, and had a son named Claire Joseph in 1768. In 1765 Dauterive entered into the agreement with Aubry, the Acadians, and Massé to raise cattle on what until then had been the latter's ranch. Upon collapse of that agreement, Dauterive somehow gained unilateral control of the land. He also owned a large plantation at Barataria, south of New Orleans, and an even 
larger one at Bayou Goula, across the Mississippi from Baton Rouge. Dauterive remained a life-long resident of New Orleans and died in 1776 beset by creditors. ${ }^{19}$

Born about 1710 in Flanders, Johannes Grevemberg arrived in Louisiana in the early 1720 s to work as a laborer on a concession along the Ouachita River, changed his name to Jean Baptiste, and acquired the nickname Flamand, meaning Flemish. He married a German immigrant named Anne Judith Chenal, and the couple had four daughters and five sons. Through the 1740s the growing family lived in New Orleans, where Grevemberg supplied the government with wood and labor for public works. He began purchasing land around 1750, including the Fausse Pointe tract from Toutin. In 1753 he traded a house lot in New Orleans to the Noyan family in return for Horn Island, a barrier island just off the coast between New Orleans and Mobile. The Noyan family had considered the island unproductive, but Grevemberg used it to raise cattle and cut pine for the New Orleans market. In the 1760s, as his sons entered their twenties and the French gave up possession of eastern Louisiana, he sold Horn Island and its five hundred head of cattle to British settlers and began to focus on the Attakapas, improving his title by securing the land grant. Grevemberg died in New Orleans in November $1771 .^{20}$

Jean François Ledée, born in 1718 in Lille, Flanders, arrived in Louisiana about 1750 after a sojourn on Martinique. He established himself as a New Orleans wholesale merchant and in 1762 purchased the land along Bayou Teche. He improved his title with the 1769 grant and by the 1770s, if not earlier, became a full-time resident of the Attakapas. He remained a bachelor and in 1785 died without heirs. ${ }^{21}$

By 1747 Joseph Deville Degoutin was living in New Orleans and had married Marie Jeanne Caron. The couple had nine children over the $1750 \mathrm{~s}$ and 1760s. Degoutin received his grant on Bayou Teche in 1764, but the notarial and other documents consistently refer to him as a resident of New Orleans until his death sometime before 1786. Caron thereafter continued to speculate in land in the Attakapas, obtaining an additional grant in 1786 for a tract of two thousand arpents on the right bank of Bayou Teche and selling the 1764 land grant to Charles Jumonville de Villiers. Neither Degoutin nor Caron seem to have lived in the Attakapas, grazed cattle there, or otherwise occupied their land along Bayou Teche. ${ }^{22}$ 
The group of non-Acadian ranchers who lacked title to land and had small herds also shared much else in common. Bonin, Tellier, and Sorrel were either from Grenoble or elsewhere in Dauphiné province. Antoine Bonin dit Dauphiné was born about 1716 in the Isère department of Dauphiné province. By the time of his 1740 marriage to Marie Marguerite Tellier, a creole born in Mobile in 1726, he had held military postings there and at Fort Toulouse. The family relocated to the Attakapas upon his discharge in 1763. Bonin seems to have begun herding cattle immediately upon arrival, registering a brand in 1764 , and having eight head of cattle by 1766 . By the 1771 census he was fifty-five years old, without slaves, with thirty-four head of cattle, and without title to land. George Tellier presumably had some relationship to Bonin's wife. He had also come to the Attakapas via Alabama but apparently a few years before the Bonin family, registering a brand in 1761. Jacques Joseph Sorrel was a long-time associate of Massé and was, like him, from Dauphiné province, born about 1736. Also like Massé, Sorrel had rich parents: Claude François Sorrel and Anne Antoinette Combet de la Rayne. He arrived in Louisiana in the early 1760 s as a military officer and moved to the Attakapas Post upon discharge in 1763. After living with Massé for several years, in 1768 he received a land grant about twenty-five kilometers downstream of Fausse Pointe, at what became the village of Sorrel, but for only six arpents of frontage and thirty of depth. His arrival in the early 1760s suggests that he registered his brand not in 1758, as claimed in the brand registry, but in 1768 when he received the grant. ${ }^{23}$

Massé also befriended another pre-Acadian rancher from Dauphiné province, Jean Baptiste Bérard. Born about 1737, Bérard settled in the Attakapas in the 1760s, married an Acadian named Anne Broussard about 1766 , registered a brand in 1767 , requested a grant in 1768 , and by 1771 had fifty-four head of cattle and title to a small tract of land. $\mathrm{He}$ also served as justice of the peace from about 1770 through his retirement in 1795, dying in 1821. One of his five children married Fuselier's eldest son, Agricole. ${ }^{24}$

Reconstructing the lives of slaves and other marginalized people such as natives and free blacks poses even greater challenges. The few records that exist are inaccurate, incomplete, and dispersed. Additionally, the dehumanization of slavery resulted in the consolidation of thousands of people with individual personal names, identities, family relationships, 
and life histories into a few categories of workers identified mainly by European surnames as well as gender and age, sometimes skin color, and more rarely origin or ethnicity. Nor do such characteristics for a given individual always appear consistently in different documents. Vague approximations of age, variable designations of skin color, arbitrary categorization of origin and ethnicity on the basis of slave ports rather than homelands, and differences between the present-day and historical ethnic geography of Africa all introduce further uncertainty. ${ }^{25}$

The vast majority of slaves in Louisiana by the 1766 census had come from Senegambia, that part of West Africa drained by the Senegal and Gambia rivers (Figure 6). Nearly six thousand enslaved Africans, some two-thirds of them male, came on twenty-three voyages between 1719 and 1743 direct from Africa to Louisiana, about two-thirds of the voyages originating in Senegambia. By the 1740s slaves had become a majority in Louisiana: out of 6,200 non-natives in 1741, approximately 4,000 were

Figure 6. West Africa with areas of open-range cattle herding, northern limit of the range of the tsetse fly, general locations of selected ethnic groups, and slave coasts.

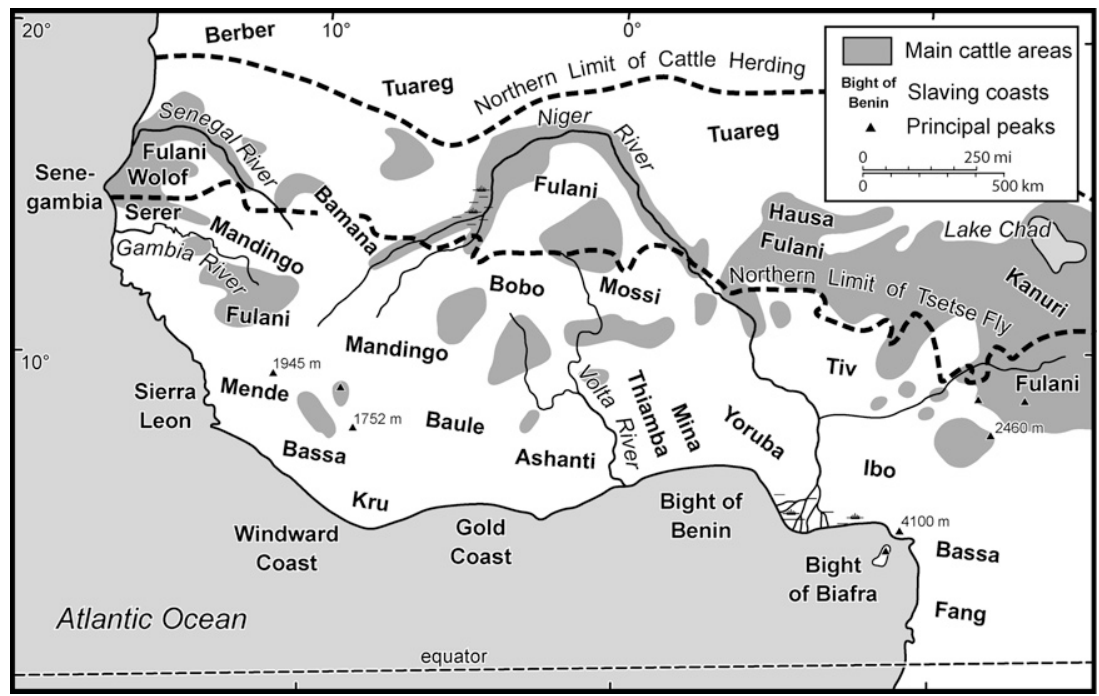

Map by author based on sources cited in text; Jordan, Frontiers, 56; Central Intelligence Agency, Africa: Ethnolinguistic Groups, map scale 1:10,400,000 (Washington, DC: CIA, 1996). 
slaves, 1,320 from Africa and 2,680 creoles, born in Louisiana. They included some Bantu speakers: Fulani, also known as Fulbe and Poulard; Wolof, or Senegal; and Serer. But most were Mande speakers: Mandingo, also known as Malinke or Maninga; Bamana, sometimes called Bambara; and Mende. With Spanish rule, slave shipments resumed but shifted to incorporate a broader spectrum than Senegambians and transshipment via the Caribbean rather than only direct voyages from Africa. ${ }^{26}$

The 1766 census again demonstrates its limitations. While the summary table claims fifty slaves for the five ranches and twenty-four for the rest of the Attakapas Post, the detailed tables account for only four on the Dauterive ranch plus twenty more living there with Massé. Since the Acadians did not have any slaves in 1766, the other twenty-six mentioned in the summary table were presumably owned by other ranchers. Of them, only Degoutin even appears in the census; he had four slaves at the time, but he and they lived in New Orleans. Nor does the census reveal anything about the names, ages, or origins of the slaves enumerated, whether twenty-four or fifty. ${ }^{27}$

The earliest volumes of records from what became Saint Martin of Tours Church in St. Martinville reveal a little about the individuals behind the census numbers. Dauterive indeed did have at least two black men at Attakapas in 1765: Claude César and Joseph, who served as witnesses at a baptism. Dauterive certainly kept many more slaves in New Orleans, Barataria, and Bayou Goula than in the Attakapas, the archives recording his numerous emancipations and sales. ${ }^{28}$

The church records also confirm that Massé had about twenty blacks living with him in 1766, although some were free rather than enslaved. Additionally, the records identify some by name and origin. One couple, Marie and Jean dit Ingui, she Wolof and he Mandingo, married in 1756 when they already had two grown daughters named Marguerite and Victoire, born in the early 1740s and therefore presumably creoles. Another couple, Pierre and Lisette, had three children that Massé emancipated upon their baptisms in 1762: Claude, Pierre, and Dominique. The records identify Lisette as black and the children as griffes (mixed African and Native American parentage), implying that Pierre was either a native or a grif. Lisette also had two older daughters: Magdaleine, born in 1749; and Françoise, born in 1753 and variously identified as a grif or mulatto. Another couple, Marie Flore and 
André Leveille, were free blacks living with Massé; they had a daughter named Claudine in 1755, who was consequently also free. Other blacks living with Massé included another man named Jean and three children named Anne, Marianne, and Pierre born about 1765 to free blacks who were formerly slaves of Massé. In addition, Massé had an Apache slave, born in 1749 and named Therese dit la Bombe. ${ }^{29}$

Records show the other ranchers holding only a few slaves. Fuselier had some by the mid-1760s that appear in the church records but not the census of 1766. At a minimum, the adults were Claude Cafar and Pierre, both black; and the children were Joseph and Marguerite, black twins born about 1762. But additional slaves who show up in the records of the late 1760s and early 1770s might well have been present as early as 1766 if not earlier, including Thomas, Marie, Jeanne, Julie, Agobard, Mathieu, Ludivine, and Guillaume. Not a single one of those records, however, refers to African origins. Grevemberg had at least one slave in the Attakapas in 1766, who did not appear in the detailed lists of the census of that year. A 1765 baptismal record names Claudine as a daughter of former black slaves of Massé, either sold or given to Grevemberg. Other Grevemberg slaves began appearing in baptismal records by the late 1770s and 1780s. One born in the mid-1760s, Henry, was Wolof but does not appear with the other Grevemberg slaves in the 1777 census so probably did not live in the Attakapas until, at the earliest, the late 1770s. Despite apparently having purchased some eighty slaves around 1760, Grevemberg had few of them at his Attakapas ranch during the 1760s. The baptismal records reveal only a single slave associated with Ledée: Louise, a mulatto girl born in 1765 . Ledée certainly had many more slaves by his death in 1785, as becomes clear from the twenty slaves listed in documents related to his succession. Only a single man, Oreste, was born early enough to have been African. The 1785 succession documents nonetheless prove particularly valuable because they record the occupation for two Attakapas slaves. And one of those two, Scipion Jean, born about 1757, was a cowboy. ${ }^{30}$

In sum, the slaves who worked on the ranches in 1766 and earlier were mainly living with Massé. Fuselier, Grevemberg, Ledée, and Dauterive had some slaves in the Attakapas but few compared to Massé. To account for the fifty slaves mentioned in the summary table of the 1766 census, then, assuming they all existed, Degoutin owned none, Massé about twenty, Fuselier perhaps a dozen, and Dauterive, Ledée, and 
Grevemberg about six each. The documents do not detail the occupations of those slaves, but they directly confirm that at least one worked as a cowboy by 1785 . The 1766 census provides no information on age or gender, but by the 1771 census about half the slaves in the Attakapas were men or teenage boys who could have been working as cowboys. By 1766, decades after the last slave imports of the French period, many would have been creole, explaining the lack of references to African origins in the records. However, the documents confirm that some slaves were Senegambians. In addition, some of the slaves were native, grif, or mulatto-of partial native or white parentage. Reconstruction of the backgrounds of the individuals involved overturns the assumption that pre-Acadian ranching knowledge and practices derived from French and Spanish antecedents in the Caribbean, principally from Hispaniola. All but one of the ranchers came to Louisiana directly from France. Ledée sojourned in the Caribbean but on Martinique, which lacked cattle ranching, and he settled in the Attakapas after Massé, Grevemberg, and Fuselier had already established their ranches. In addition, the blacks living in the Attakapas were Louisiana creoles or had come directly from Africa, not the Caribbean. ${ }^{31}$

Ruling out the Caribbean as a node in the relevant networks might suggest Europe as a key source of ranching knowledge, yet none of the evidence demonstrates that any of the whites brought useful experience from France. The only open-range cattle herding in France occurred in the marshlands of the delta of the Rhône River and in the hill lands of the Auvergne and Brittany. Flanders, the birthplace of Grevemberg and Ledée, is well north of Brittany and the Auvergne. Lyons, Fuselier's birthplace, is east of the Auvergne and, while on the Rhône, much nearer its headwaters than its delta. Grenoble and surrounding Dauphiné province as well as Belley—birthplaces of Dauterive, Massé, and the small ranchers-are all in the foothills of the Alps. ${ }^{32}$

In contrast, the evidence demonstrates that some of the blacks at least could have had direct knowledge of cattle herding. Senegambia occupies the western end of the sub-Saharan steppes that was one of the Atlantic world's centers of open-range cattle herding during the slaving voyages that brought some four thousand Senegambians to Louisiana by 1743 . Cattle herding extended from the coast far up the Senegal and Gambia rivers and involved all of the ethnic groups reported in Louisiana 
generally, and the Attakapas specifically. The Wolof, Serer, Mandingo, Mende, and Bamana grew sorghum, millet, and rice in conjunction with raising livestock. When the rains came in May or June and the crops began to germinate, those groups sent their cattle northward with Fulani, who specialized in cattle herding, to graze the open range of the Sahel Belt as far north as the fringes of the Sahara. As the rains ended in September or October and the Sahel turned from green to brown, the Fulani returned southward to the river valleys of Senegambia to graze the herds on the stubble of the harvested crops, manuring those fields in the process. The open range provides the most basic similarity between Senegambia and the Attakapas but so does the seasonal movement between complementary pastures. ${ }^{33}$

Much also differed, however. Senegambian cattle do not run feral. The herders castrated the majority of bulls, paddocked the entire herd nightly, and milked the cows daily. The castration and close contact resulted in docile cattle and permitted Senegambians to herd on foot rather than horseback. Also, the seasonal movement between pastures involved long rather than short distances; and cattle herding and cropping had a complementary relationship. Beyond such major distinctions, various details also varied, such as the use of earmarking rather than branding. ${ }^{34}$

Given the lack of prior experience with branding and herding from horseback among both the whites and the blacks, those and other practices might have filtered into the Attakapas from the Caribbean. Grevemberg provides a possible indirect connection to Caribbean ranching because Horn Island must have, just like the rest of eastern Louisiana, imported cattle from Saint-Domingue and Cuba. Andalusians had established branding in the Spanish Caribbean, and the French who took over western Hispaniola as the French colony of Saint-Domingue in the late 1600s continued the practice. Grevemberg, the only pre-Acadian rancher of the Attakapas definitely known to have also ranched in eastern Louisiana, might well have acquired branded Caribbean cattle to stock Horn Island in the early 1750s, which would explain why he became the first rancher to register brands in the Attakapas. He would have had no reason to employ branding on Horn Island, but he might well have become aware of it there and then introduced it into the Attakapas, where the value of branding would have been clear given the mixing of the feral herds of the various ranchers on an open range. As for mounted herding, 
no direct evidence occurs of that practice on the five pre-Acadian ranches, but according to the 1766 census they had three hundred horses among them, certainly suggestive of a need for mounts to herd the fifteen thousand cattle. Senegambians and the French both had much experience with horses-except in the singular case of the Rhône Delta-for transportation and warfare rather than herding. ${ }^{35}$

Tejanos did brand cattle and herd from horseback, and both practices might therefore have come into the Attakapas from the west. Massé had experience as far into Texas as the Trinity River, but no evidence remains that he ever used a brand. The natives and griffes who lived with Massé on his ranch might also have introduced branding and mounted herding, since the Avoyelles, Apaches, and Ishaks all traded cattle, whether feral or rustled, from Texas into Louisiana. ${ }^{36}$

Despite the assumptions of the existing literature, the earliest largescale ranching in Louisiana did not derive from French ranchers on SaintDomingue or anywhere else in the Caribbean, and its herding ecology did not resemble the Acadian system that emerged on the prairies to the west in the late eighteenth century. Instead, people of African, European, native, and mixed origins participated in a creole act of creation through which a herding ecology emerged that worked in the particular environment around the Attakapas Post. Although more evidence suggests that black slaves brought relevant knowledge from Africa than that white ranchers brought any from Europe, reconstruction of local social and environmental relations demonstrates just how problematic such categories can be. Instead of a clear dichotomy between powerful free whites and powerless enslaved blacks, some whites had land, slaves, and capital while others did not; some blacks were slaves while others were not; and many of the actors had mixed origins that included native ones. Whether or not the sources can ever more fully reveal the complex processes involved remains an open question, but they have certainly exposed as specious the assumption that whites played the main creative role.

\section{NOTES}

1. The Attakapas Post was at present-day St. Martinville. Attakapas 1766, fol. 1-52, leg. 2595, Sección Gobierno, Audiencia de Santo Domingo, Archivo General de Indias, Sevilla, Spain (hereafter SGASD); Terry G. Jordan, North American Cattle-Ranching Frontiers: Origins, Diffusion, and Differentiation (Albuquerque: University of New Mexico Press, 
1993), 121, 311-12; Reports of Apr. 30 and Sept. 30, 1765 from Aubry and Foucault to Etienne François de Choiseul and Account of Apr. 30, 1765 by Foucault listing goods supplied to the Acadians, fols. 21-24, 30-30v, 31-33, Vol. 45, Correspondance à l'Arrivée en Provenance de la Louisiane, Séries C13a, Archives Nationales d'Outre-mer, Aix-enProvence, France (hereafter ANO). For a detailed account of the Acadian settlement of Louisiana, see, Carl A. Brasseaux, The Founding of New Acadia: The Beginnings of Acadian Life in Louisiana, 1765-1803 (Baton Rouge: Louisiana State University Press, 1987). A league measured both distance and area, with each square league measuring 4,916 meters on a side and therefore containing 2,417 hectares, see, Roland Chardon, "The Linear League in North America," Annals of the Association of American Geographers (June 1980): 129-53.

2. Jordan, Frontiers, 120-22; Lauren C. Post, Cajun Sketches: From the Prairies of Southwest Louisiana (Baton Rouge: Louisiana State University Press, 1962); Lauren C. Post, "The Domestic Animals and Plants of French Louisiana as Mentioned in the Literature, with Reference to Sources, Varieties, and Uses," Louisiana Historical Quarterly (Oct. 1933): 554-86; James W. Taylor, "The Agricultural Settlement Succession on the Prairies of Southwest Louisiana" (PhD diss., Louisiana State University, 1956); Bill Jones, Louisiana Cowboys (Gretna, La.: Pelican Publishing, 2007). The proportion of Acadian households in the Attakapas district that owned slaves increased from less than 4 percent in 1794 to 56 percent in 1810; Brasseaux, Founding, 188-97.

3. The United States considered all of Louisiana to be public land except for those tracts individuals had acquired through grants from the French or Spanish governments or through purchase from native peoples. The General Land Office accumulated evidence of colonial land grants and their subsequent subdivision and conveyance to make recommendations to Congress regarding the validity of each claim. The resulting archive ranges from the evidence of colonial documents and transcripts of testimony, through case summaries and reports, acts of Congress confirming approved claims, surveys and patents, and original plat maps for each township. General Land Office reports to Congress appear in the American State Papers: Public Lands, 8 Vols. (Washington, DC: Gales and Seaton, 1832-61). The Louisiana State Land Office (hereafter SLO) retains some of the documentation, which is available online at the Division of Administration, State of Louisiana, doa.louisiana.gov (accessed on Oct. 21, 2011).

4. Grant of Mar. 2, 1765 to Massé and Dauterive, Louisiana Land Grants 1753-1769, Tulane University, New Orleans, La. (hereafter TU); Sworn statement of Aug. 20, 1771 by Dauterive, Folder 1771/08/03-01, Cabildo Records, Louisiana State Museum Historical Center, New Orleans, La. (hereafter CR); Report of Apr. 24, 1765 by Aubry to Choiseul, fols. 47-52v, Vol. 45, ANO; 1765 Appraisals of Dauterive's property, Nos. 37-41, Vol. 1 (1760-1779), Volumes of Original Acts, St. Martin Parish Courthouse, St. Martinville, La. (hereafter VOA); Survey of Apr. 10, 1798 by Gonsoulin for Louis and Alexandre de la Houssa, No. G27, Louisiana Land Surveys, Louisiana Manuscripts, Clements Library, University of Michigan-Ann Arbor, Ann Arbor, Mich. (hereafter Louisiana Land Surveys); Brief of Complaints by the Dauterive Heirs, MS 2001-246-RL.13, Historic New Orleans Collection, New Orleans, La. (hereafter HNOC); Stephen K. Williams, ed., Cases Argued and Decided in the Supreme Court of the United States and Others, Bk. 13, 18501851 (Rochester: Lawyers' Cooperative Publishing, 1901), 560-68; American State Papers, 2:744-871; Claim by the Attakapas Church, pp. 210-11, Vol. 22, Claim Papers for the Southwestern District (hereafter Claim Papers SWD); Abstracts of French and Spanish Grants, pp. 6-7; Claims of the Dauterive heirs, pp. 95-106, Pt. 2, Bk. 1, Opelousas Land 
Claims; Original Township Plat for T11S, R6E SWD, Dec. 23, 1845; Resurvey of T10S, R5E SWD, Apr. 23, 1856; Resurvey of T10S, R6E SWD, Feb. 4, 1881; Resurvey of T10S, R7E SWD, Dec. 17, 1846, SLO.

5. The French and Spaniards called the Ishak people the Attakapas, a derogatory Choctaw term meaning cannibal. See, Fred B. Kniffen et al., The Historic Indian Tribes of Louisiana: From 1542 to Present (Baton Rouge: Louisiana State University Press, 1987). Abstracts of French and Spanish Grants, pp. 6-7; Petition of July 16, 1765 by Grevemberg to Aubry and Claim by Elizabeth Taley, pp. 162-65, 306, Pt. 2, Bk. 1, Opelousas Land Claims; Claim by the Attakapas Church, pp. 210-11, Vol. 22; Testimony recorded prior to Apr. 10, 1813, p. 216, Vol. 20; Claim by the legal representatives of Sam Fuselier, pp. 158-65, Vol. 18; Claim by Patrick Morgan and Daniel Clark, pp. 73-77, Vol. 37, Claim Papers SWD; Original Township Plat for T11S, R6E SWD, Dec. 23, 1845; Original Township Plat for T11S, R7E SWD, Dec. 28, 1875; Original Township Plat for T7S, R5E SWD, Sept. 27, 1845; Resurvey of T8S, R5E SWD, June 18, 1855; Resurvey of T9S, R5E SWD, June 18, 1855; Resurvey of T9S, R6E SWD, June 30, 1854; Resurvey of T10S, R5E SWD, Apr. 12, 1856; Resurvey of T8S, R6E SWD, Apr. 26, 1855; Original Township Plat for T7S, R6E SWD, Apr. 26, 1855; Testimony of Andrew Martin, pp. 11-13, Private Claims in Opelousas District, SLO; Survey of Apr. 10, 1798 by Gonsoulin for Louis and Alexandre de la Houssa, No. G27; Survey of 1799 by Trudeau for Jumonville de Villiers, No. G12, Louisiana Land Surveys; Report of Mar. 14, 1756 from Viceroy Amarillas on Blancpain's arrest, fols. 166-67v, exp. 72, Vol. 1, Ser. 1, Correspondencia de los Virreyes, Archivo General de la Nación, Mexico City (hereafter CV); Ordinance of Feb. 18, 1770 by O'Reilly, fols. 7-8, exp. 2, leg. 188A, Sección Papeles Procedentes de Cuba, Archivo General de Indias, Sevilla, Spain (hereafter PPC).

The ordinance specified that agricultural grants would have six to eight arpents of stream frontage and forty arpents extending back from the stream. Owners of large herds of cattle qualified for larger grants: half a league square for every hundred head up to a maximum of either one league of frontage by one league of depth, or, if topography or prior grants made that impossible, one-and-a-half leagues of frontage by a half league of depth.

Brasseaux, Founding, 193; Anonymous draft survey of 1793 for Arthur Strother; Uncatalogued 1799 survey by Trudeau for Charles Jumonville de Villiers, Folder for Attakapas, Survey Collection, Louisiana and Lower Mississippi Valley Collections, Louisiana State University, Baton Rouge, La. (hereafter LLMVC); Survey of May 20, 1793 by Gonsoulin for Strother, fols. 182-83v, Cont. 6 (1790-91), Louisiana Miscellany, Manuscript Division, Library of Congress, Washington, DC; Estate sale of May-June 1785 of Ledée's goods, No. 68, Vol. 4 (1784-85), VOA; Copy of Mar. 5, 1795 by Trudeau of survey for Strother, No. G30; Survey of June 20, 1800 by Trudeau for Marie Babin, No. G38, Folder for Attakapas 1793-1803, Louisiana Land Surveys; American State Papers, 3:77-150, 5:736-39, 3:151-62, 2:744-871; Sale of land by Jung to Ledée on Mar. 8, 1762, Folder 1762/03/08-04, Superior Council Records, Louisiana State Museum Historical Center, New Orleans, La. (hereafter SCR); Grant of Feb. 19, 1769 to Ledée; Grant of June 13, 1764 to Degoutin, Louisiana Land Grants 1753-69, TU; Estate sale on Mar. 14, 1786 of Ledée's land, Documents of the Opelousas Post, 1764-1789, Louisiana State Archives, Baton Rouge, La. (hereafter LSA); Chardon, "Linear League in North America."

6. Petition of July 16, 1765 by Grevemberg to Aubry, p. 162, Pt. 2, Bk. 1, Opelousas Land Claims, SLO.

7. "Early Cattle on Rancho and Vacherie," Folder 149, Box 4, Lauren Chester Post Papers, LLMVC; Daniel H. Usner, Indians, Settlers, and Slaves in a Frontier Exchange 
Economy: The Lower Mississippi Valley Before 1783 (Chapel Hill: University of North Carolina Press, 1992), 176-80; Antoine Simon le Page du Pratz, Histoire de la Lousiane, 3 Vols. (Paris: Chez de Bure, 1758), 1:297; H. Sophie Burton and F. Todd Smith, Colonial Natchitoches: A Creole Community on the Louisiana-Texas Frontier (College Station: Texas A\&M University Press, 2008), 146-67; Post, "Domestic Animals and Plants," 559_ 63; John D. W. Guice, "Cattle Raisers of the Old Southwest: A Reinterpretation," Western Historical Quarterly (Apr. 1977): 167-87, 173; Jordan, Frontiers, 120-21.

8. Brasseaux, Founding, 92; Attakapas 1766, fols. 1-52, leg. 2595, SGASD.

9. Attakapas 1766, fol. 26, leg. 2595, SGASD.

10. Herbert E. Bolton, "Spanish Activities on the Lower Trinity River, 1746-1771," Southwestern Historical Quarterly (Apr. 1913): 339-77; Letter of July 22, 1756 from Barrios to Viceroy Amarillas, fols. 289-91v, exp. 119, Vol. 1, Ser. 1, CV; Petition of July 16, 1765 by Grevemberg to Aubry, p. 162, Pt. 2, Bk. 1, Opelousas Land Claims, SLO; Attakapas y Opelousas 1771, fol. 42-47, leg. 188C, PPC; Sworn statement of Aug. 20, 1771 by Dauterive, Folder 1771/08/03-01, CR.

11. The St. Martin Parish Courthouse has the two earliest brand books: Brand Book A and Brand Book B. The Brand Book for Opelousas and Attakapas Districts, 1739-1888 is in the Special Collections, University of Louisiana-Lafayette (hereafter ULL-Brand Book).

12. ULL-Brand Book, 68, 135, 339, 146; Brand Book A, 81; Brand Book B, 10, 155, 31; Attakapas y Opelousas 1771, fol. 43v, leg. 188C, PPC; Attakapas 1766, fol. 11, leg. 2595, SGASD; Burial of Oct. 7, 1800 of Anne Tellier, No. 217, Registre de Enterrements de 1787-1830, St. Martin of Tours Catholic Church, St. Martinville, La. (hereafter SMT); Winston Deville, Colonial Louisiana Marriage Contracts, Vol. 5, Marriage Contracts of the Attakapas Post, 1760-1803 (St. Martinville: Attakapas Historical Association, 1967), 6.

13. Several other names appear in the brand books with dates before 1766 , but all seem, on the basis of the registrants' biographies and comparison across the three books, to be the result of poor copying or backdating and therefore spurious.

14. Post, Cajun Sketches, 38-46; Jordan, Frontiers, 66, 84-85, 120-21, 96-100, 124, $156-$ 57, 178-79, 184-89; Brasseaux, Founding, 144, 171-72.

15. Fred B. Kniffen and Sam B. Hilliard, Louisiana: Its Land and People (Baton Rouge: Louisiana State University Press, 1988), 51-52; Diario del viaje de la ciudad a los Attakapas, Opelousas, y Natchitoches (1769-70), fols. 434-42, leg. 2357; Reports of Apr. 21, May 16, May 20, June 30, July 9, 1779 from Bouligny to Gálvez, fols. 134-47v, leg. 2358, PPC.

16. Robin, Voyages dans l'Intérieur, 3:28-31.

17. Marriage contract of Apr. 29, 1771 between Fuselier and Soileau, No. 385, Vol. 4 (1784-85), VOA; Marriage of Apr. 30, 1771 between Fuselier and Soileau, pp. 22-23, Vieux Registre de 1756-94, SMT; Attakapas y Opelousas 1771, fol. 47, leg. 188C; Attakapas y Opelousas de 1777, fol. 260, leg. 2358; Draft letter of Feb. 18, 1770 from O'Reilly to Fuselier, fol. 9-9v, exp. 2, leg. 188A, PPC; Archdiocese of New Orleans, Archdiocese of New Orleans Sacramental Records, 19 Vols. (New Orleans: Archdiocese of New Orleans, 1987-2004), 2:132; Diocese of Baton Rouge, Diocese of Baton Rouge Catholic Church Records, 23 Vols. (Baton Rouge: Diocese of Baton Rouge, 1978-2007), 3:49, 302; Glenn R. Conrad, ed., A Dictionary of Louisiana Biography, 2 Vols. (Lafayette: University of Louisiana Press, 1988), 1:328-29; Winston DeVille, Gabriel Fuselier de la Claire: His Death and Succession, 1789-1790 (Ville Platte, La.: Provincial Press, 2003).

18. Exhibit A, p. 99, Pt. 2, Bk. 1, Opelousas Land Claims, SLO; Grant of Mar. 2, 1765 to Massé and Dauterive, Louisiana Land Grants 1753-69, TU; Attakapas y Opelousas 
1771, fol. 44v, leg. 188C, PPC; Attakapas 1766, fol. 11, leg. 2595; Letter of Apr. 27, 1776 by Unzaga re. the Massé estate, fol. 61, leg. 2547, SGASD; Petition of Jan. 10, 1785 by Francisco Broutin on behalf of Claudio Trenonay, Folder 1785/01/10-002, CR; Baptisms of June 5, 1756 of Massé's slaves, pp. 1-3, Vieux Registre de 1756-94, SMT; Robin, Voyages dans l'Intérieur, 3:20-21.

19. Claims of the Dauterive heirs, pp. 95-106, Pt. 2, Bk. 1, Opelousas Land Claims, SLO; Copy of Nov. 30, 1830 of the Mar. 2, 1765 grant to Massé and Dauterive, Kuntz Collection, TU; Marriage of July 2, 1793 between Dauterive and Latille, No. 83, Vieux Registre de 1787-1802, SMT; fols. 67316-17, Folder 36 (1762), Box 4, Chantalou; fol. 99, Bk. 1 (1771), Almonester y Roxas; fols. 150v-52v, 168-69, 169v-70, 222, Bk. 2 (1771), Garic, New Orleans Notarial Archives, New Orleans, La. (hereafter NONA); Proceedings in July-Nov. 1771 by Antonio Barnabé versus Dauterive, Folders 1771/07/06-01 and 1771/ 08/03-01; Inventory of Feb. 6, 1773 of the property of de Vaugine, Folder 1773/02/06-01, CR; Winston DeVille, Louisiana Troops, 1720-1770 (Fort Worth: American Reference Publishers, 1965).

20. Marriage Contract of Jan. 21, 1786 between Grevemberg and Boisdore, No. 75, Vol. 41/2 (1786), VOA; Baptism of May 31, 1798 of Grevemberg, No. 57, Libro de Baptismos de Blancos, 1797-1803, SMT; Attakapas y Opelousas 1771, fol. 43v, leg. 188C, PPC; fols. 142v-43v, 161-62, 327, 331, Bk. 2 (1771), Garic, NONA; Archdiocese of New Orleans, Archdiocese of New Orleans Sacramental Records, 1:123; Documents of Oct. 26Nov. 5, 1753 re. Noyan family meeting, Folders 1753/10/31-01, 1753/11/05-01; July 5, 1766 sale of Horn Island by Grevemberg to Farmar, Folder 1766/07/05-01, SCR.

21. fol. 95, Bk. 3 (1772), Garic; fols. 216-22v, Bk. 4 (1785), Fernando Rodriguez, NONA; Testimony of Andrew Martin, p. 12, Private Claims in Opelousas District, SLO; Estate sale of May-June 1785 of Ledée's goods, No. 68; Probate inventory of May 2, 1785 of Ledée's property, No. 101, Vol. 4 (1784-85), VOA; Mar. 14, 1786 estate sale of Ledée's land, Documents of the Opelousas Post, 1764-1789, LSA; Attakapas y Opelousas 1771, fols. 42-47, leg. 188C, PPC; Archdiocese of New Orleans, Archdiocese of New Orleans Sacramental Records, 4:188.

22. Attakapas 1766, fol. 22, leg. 2595, SGASD; Grant of June 13, 1764 to Degoutin, Louisiana Land Grants 1753-69, TU; fols. 334-40, 352v-54, Bk. 3 (1773), Almonester y Roxas; fols. 148v-49v, Bk. 4 (1773), Garic, NONA; Archdiocese of New Orleans, Archdiocese of New Orleans Sacramental Records, 1:81, 2:93-94.

23. Marriage contract of June 8, 1779 between Bonin and Prevot, No. 104, Vol. 1 (176079), VOA; Marriage of Jan. 9, 1779 between Bonin and Prevot, pp. 71-72, Vieux Registre de 1756-94; Burial of Oct. 7, 1800 of Anne Tellier, No. 217, Registre de Enterrements de 1787-1830, SMT; ULL-Brand Book, 339, 146, 135; Attakapas y Opelousas 1771, fols. 43v-44, leg. 188C, PPC; Diocese of Baton Rouge, Diocese of Baton Rouge Catholic Church Records, 2:104; Archdiocese of Mobile, Sacramental Records of the Roman Catholic Church of the Archdiocese of Mobile, 1704-1739 (Mobile: Archdiocese of Mobile, 2002), 169, 296; Jacqueline Olivier Vidrine, Love's Legacy: The Mobile Marriages Recorded in French, Transcribed, with Annotated Abstracts in English, 1724-1786 (Lafayette: University of Louisiana Press, 1985), 208-11; Johnnie Andrews, Fort Toulouse Colonials: A Compendium of the Colonial Families of Central Alabama, 1717-1823 (Prichard, Ala.: Bienville Historical Society, 1987), 3; DeVille, Louisiana Troops, entry for Bonin; Deville, Colonial Louisiana Marriage Contracts, 5:6, 39; Grant of June 1, 1768 to Sorrel by Ulloa, MS 79, Folder 2, HNOC; Robin, Voyages dans l'Intérieur, 3:22-23; 
Gertrude C. Taylor, "Fortune and Misfortune: The Sorrel Family in Louisiana, 17631900," Attakapas Gazette 21 (Winter 1986): 179-91.

24. Election of May 16, 1770 of an assistant to Bérard, No. 7, Vol. 1 (1760-79), VOA; Claim of Landry of Dec. 29, 1806, pp. 251-52, Vol. 53, Claim Papers SWD, SLO; Attakapas y Opelousas 1771, fol. 44v, leg. 188C, PPC; Robin, Voyages dans l'Intérieur, 3:22-23; Deville, Colonial Louisiana Marriage Contracts, 5:55; Vidrine, Love's Legacy, 319; Tamara D. McGinnis, "Last Will and Testament of Jean Berard," Attakapas Gazette 23 (Spring 1988): 81-83.

25. Gwendolyn Hall, Slavery and African Ethnicities in the Americas: Restoring the Links (Chapel Hill: University of North Carolina Press, 2005), 22-54; David Eltis et al., The Trans-Atlantic Slave Trade: A Database on CD-ROM (Cambridge: Cambridge University Press, 1999).

26. Hall, Slavery, 43-44; Gwendolyn Hall, Africans in Colonial Louisiana: The Development of Afro-Creole Culture in the Eighteenth Century (Baton Rouge: Louisiana State University Press, 1992), 9-10, 34-35, 40-45, 60, 171-75.

27. Attakapas 1766, fols. 10v-11, 22, leg. 2595, SGASD.

28. Baptisms of Sept. 1, 1765 of Joseph and Marguerite, p. 11, Vieux Registre de 175694; Baptisms of Sept. 1, 1765 of Joseph and Marguerite, p. 2, Slave Register 1765-1818, SMT; fol. 99, Bk. 1 (1771), Almonester y Roxas; fols. 150v-52v, 168-69, 169v-70, 222, Bk. 2 (1771), Garic, NONA.

29. Baptisms on June 2, 1765 of Anne, Pierre, Marianne, and Claudine, p. 1, Slave Register 1765-1818; Baptisms on June 5, 1756 of Therese, Claudine, Marie, Jean, Marguerite, Victoire, Magdaleine, and Françoise; Marriage on June 5, 1756 of Marie and Jean dit Ingui; Baptisms on Feb. 18, 1762 of Claude, Dominique, and Pierre, pp. 1-6, Vieux Registre de 1756-94, SMT.

30. Baptisms on June 2, 1765 of Anne, Pierre, Marianne, and Claudine, p. 1; Baptisms on Apr. 7, 1782 of Rossete and on May 21, 1782 of François Anselme and Charles, p. 5, Slave Register 1765-1818; Baptism on Feb. 18, 1762 of Claude, p. 4; Baptism on June 2, 1765 of Claudine, p. 6; Baptisms on Sept. 1, 1765 of Joseph and Marguerite, p. 11; Baptisms on Jan. 8, 1766 of Louise and Apr. 21, 1771 of Catherine, p. 16; Baptisms on Apr. 21, 1771 of Rose and Jean Baptiste, p. 17; Marriage on Apr. 26, 1771 of Françoise and Guillaume, p. 22; Baptisms on July 13, 1772 of Félicité and Augustin, p. 24; Baptism on May 4, 1773 of Jean Pierre, p. 38; Baptism on Nov. 24, 1776 of François, p. 50; Baptism on Dec. 1, 1776 of Alexandre, p. 51; Baptisms in 1788-90 of Jean Baptiste and Henry, p. 73, Vieux Registre de 1756-94, SMT; Attakapas y Opelousas de 1777, fol. 261, leg. 2358, PPC; Petition of Oct. 1, 1763 by Chantalou, Folder 1763/10/01-02, SCR; Probate inventory of May 2, 1785 and Estate sale of May-June 1785, Nos. 68 and 101, Vol. 4 (1784-85), VOA.

31. Jordan, Frontiers, 66, 84-85, 120-21, 188.

32. Ibid., 16, 84.

33. Hall, Africans, 60, 171-72; George E. Brooks, Eurafricans in Western Africa: Commerce, Social Status, Gender, and Religious Observance from the Sixteenth to the Eighteenth Century (Athens: Ohio University Press, 2003), 1-36; Jordan, Frontiers, 5564; Judith A. Carney, Black Rice: The African Origins of Rice Cultivation in the Americas (Cambridge: Harvard University Press, 2001), 46-49; Mahdi Adamu and A. H. M. Kirk-Greene, ed., Pastoralists of the West African Savanna: Selected Studies Presented at the Fifteenth International African Seminar, held at Ahmadu Bello University, Nigeria, July 1979 (Manchester, UK: Manchester University Press, 1986); Andrew B. Smith, 
Pastoralism in Africa: Origins and Development Ecology (Athens: Ohio University Press, 1992).

34. Jordan, Frontiers, 310.

35. Attakapas 1766, fol. 26, leg. 2595, SGASD; Post, "Domestic Animals and Plants," 559-63; Jordan, Frontiers, 120-21.

36. Post, "Early Cattle on Rancho and Vacherie"; Usner, Indians, Settlers, 176-80; Page du Pratz, Histoire de la Louisiane, 1:297. 